\title{
PENGARUH PENDIDIKAN KESEHATAN MELALUI METODE CERAMAH DENGAN METODE DISKUSI TERHADAP PENGETAHUAN DAN SIKAP TENTANG NARKOTIKA, PSIKOTROPIKA, ZAT ADIKTIF (NAPZA) PADA SISWA SMU SWASTA RK DELI MURNI DISKI KECAMATAN SUNGGAL KABUPATEN DELI SERDANG TAHUN 2016
}

\author{
Merlina Sinabariba
}

\begin{abstract}
From the observation, it was found some students of Private High School of RK Deli Murni comsumed Narcotics, Psychotropica, Addictive Substances (NAPZA). This was caused by lack of knowledge and attitudes about NAPZA, so it is necessary to do health education to increase student's knowledge and attitude. Health education can be done by using lecture and discussion methods. The research objective was to understand the effects of health education through lecture and discussion method on knowledge and attitudes about NAPZA among students of Private High School RK Deli Murni Diski, Sunggal Subdistrict, Deli Serdang District.

The type of research was quasi experimental design with Pretest-Posttest Group Design. The population included all the students in Private High Schools of RK Deli Murni. The samples were 60 students and divided into two groups: 30 students were in lecture group and 30 students were in discussion group. The analysis of the data used Independent t-test.

The result of the research showed there was an effect of health education through lecture and discussion method toward knowledge $(p=0.031)$ and the attitude $(p=0,011)$. The mean of knowledge in lecture group was 5,03 with deviation standard was 1,75 and the mean of knowledge in discussion group was 5,93 with deviation standard was 1,39. The mean of attitude in lecture group was 7,07 with the deviation standard was 3,06 and the of attitudein discussion group was 8,93 with deviation standard was 2,41.

It is suggested to School Master of Private High School of RK Deli Murni to use discussion method in delivering message about NAPZA to the students because it was proved more excelent than lecture method to increase student's knowledge and attitude. It is needed to make collaboration with health office to give health education especially about NAPZA.
\end{abstract}

Keywords: NAPZA, Lecture, Discussion, Knowledge, Attitude

\section{PENDAHULUAN}

Kesehatan sebagai salah satu unsur kesejahteraan umum harus diwujudkan sesuai dengan cita-cita bangsa Indonesia sebagaimana dimaksud dalam pembukaan Undang-Undang Dasar 1945 melalui pembangunan nasional yang berkesinambungan berdasarkan Pancasila dan Undang-Undang Dasar 1945. Pembangunan kesehatan diarahkan untuk mempertinggi derajat kesehatan, yang besar artinya bagi pengembangan dan pembinaan sumber daya manusia Indonesia dan sebagai modal bagi pelaksanaan 
pembangunan nasional yang pada hakikatnya adalah pembangunan manusia Indonesia seutuhnya dan pembangunan seluruh masyarakat Indonesia. Dengan memperhatikan peranan kesehatan di atas, diperlukan upaya yang lebih memadai bagi peningkatan derajat kesehatan dan pembinaan penyelenggaraan upaya kesehatan secara menyeluruh dan terpadu. Upaya bidang kesehatan khususnya bertujuan untuk mencapai kemampuan hidup bagi setiap penduduk, terwujudkan derajat kesehatan yang optimal melalui upaya kesehatan yang menyeluruh dan terpadu terhadap berbagai masalah Nasional yang timbul dengan peran serta aktif masyarakat sebagai penunjang (UU Kesehatan No. 36 tahun 2009).

Menurut data Badan Narkotika Nasional (2006), angka tindak pidana narkotika di Indonesia juga meningkat tajam yaitu sekitar 205\% dari tahun 2003 sampai dengan 2006. Penggunaan NAPZA dengan cara suntik juga menjadi salah satu faktor yang memicu peningkatan infeksi HIV (Sumiati, 2009).

Menurut UU No.22 tahun 1997 tentang narkotika, yang dimaksud dengan Narotika adalah zat atau obat yang berasal dari tanaman atau bukan tanaman, baik sintesis maupun semisintesis, yang dapat menyebabkan penurunan atau perubahan kesadaran, hilangnya rasa, mengurangi sampai menghilangkan rasa nyeri, dan dapat menimbulkan ketergantungan. Psikotropika menurut UU RI No. 5 tahun 1997 adalah zat atau obat baik alamiah maupun sistesis bukan narkotika, yang berkhasist psikoaktif melalui pengaruh selektif pada susunan saraf pusat yang menyebabkan perubahan khas pada aktifitas mental dan perilaku dan zat adiktif adalah bahan yang menyebabkan adiksi atau ketergantungan yang membahayakan kesehatan dengan ditandai perubahan perilaku, kognitif, dan fenomena fisiologis, keinginan kuat untuk mengkonsumsi bahan tersebut, kesulitan dalam megendalikan penggunaannya, memberi prioritas pada penggunaan bahan tersebut dari pada kegiatan lain, meningkatnya toleransi dan dapat menyebabkan keadaan gejala putus, dalam perkembangannya remaja sangat rentan terhadap pengaruh lingkungan.

Menurut Lin dalam Kusmiran (2001), masa remaja merupakan masa transisi dari masa kanak-kanak menuju dewasa dimana pada masa ini remaja mengalami perubahan yang bersifat universal yaitu peningkatan emosi, perubahan fisik, perubahan terhadap minat dan peran, perubahan pola prilaku, nilai-nilai dan sikap ambivalen terhadap perubahan. Jumlah SMU swasta RK Deli Murni Diski Kecamatan Sunggal Kababupaten Deli Serdang kelas X berjumlah 66 orang, kelas XI berjumlah 60 orang dan kelas XII berjumlah 50 orang mengingat para siswa SMU swasta RK Deli Murni Diski Kecamatan Sunggal Kababupaten Deli Serdang adalah remaja dan usia pelajar sangat rentan terhadap NAPZA. Tanpa ada pengawasan dan informasi yang benar tentang bahaya NAPZA sangat berbahaya bagi remaja terutama terhadap kesehatan reproduksinya. Dampak narkoba terhadap kesehatan reproduksi pada remaja perempuan terjadi penurunan dorongan seks, gangguan pada hormon estrogen dan progesteron, kegagalan orgasme, hambatan menstruasi, pengecilan payudara, gangguan sel telur, serta pada wanita hamil dapat 
menyebabkan kekurangan gizi sehingga bayi yang dilahirkan juga dapat kekurangan gizi, berat badan bayi rendah, bayi cacat serta dapat menyebabkan bayi keguguran. Dampak kesehatan reproduksi pada remaja laki-laki dapat mengakibatkan terjadinya penurunan kadar hormon testosteron, penurunan dorongan seks, disfungsi ereksi, hambatan ejakulasi, pengecilan ukuran penis dan gangguan sperma (Mardiani, 2013).

SMU swasta RK Deli Murni Diski, adalah salah satu SMU di Kecamatan Sunggal Kabupaten Deli Serdang yang termasuk kedalam sekolah favorit dimana siswanya berasal dari latar belakang yang berbeda-beda. Sekolah ini adalah salah satu sekolah favorit yang sudah pernah mendapatkan penyuluhan kesehatan tentang NAPZA baik itu dari LSM (Lembaga Swadaya Masyarakat) maupun dari tim kesehatan secara langsung.

Berdasarkan hasil observasi dan mengadakan wawancara kepada beberapa siswa mereka mengatakan sering kumpul-kumpul di warung disamping sekolah, dan pernah ada penyuluhan tetapi dari 20 orang ada 14 orang (70\%) yang kurang pengetahuan dan sikapnya tentang Napza, bahkan ditemukan siswa yang berseragam sekolah sedang merokok didalam angkot dan turun didepan sekolah. Selama tinggal di daerah Diski banyak diperkirakan pengguna NAPZA dimana kemungkinan SMU Swasta RK Deli Murni Diski Kecamatan Sunggal Kabupaten Deli serdang menjadi salah satu target pengedaran NAPZA ditambah lagi sekolah ini merupakan sekolah yang berada di pertengahan antara Kota Binjai dan Kota Medan yang rentan menjadi sasaran pengedaran NAPZA. $\begin{array}{lrr}\text { Sikap } & \text { seseorang } & \text { terhadap } \\ \text { suatu objek menunjukkan } & \text { tentang } \\ \text { pengetahuan individu } & \text { tersebut } \\ \text { terhadap objek sikap r yang } \\ \text { bersangkutan, }\end{array}$ dipengaruhi oleh faktor pendidikan formal. Pengetahuan sangat erat hubungannya dengan pendidikan, dimana diharapkan bahwa dengan pendidikan yang tinggi maka orang tersebut akan semakin luas pula pengetahuannya. Akan tetapi perlu ditekankan, bukan berarti seseorang yang berpendidikan rendah mutlak berpengetahuan rendah pula. Hal ini mengingat bahwa peningkatan pengetahuan tidak mutlak diperoleh dari pendidikan formal saja, akan tetapi dapat diperoleh melalui pendidikan non formal (Wawan dan Dewi, 2011).

Perlu dilakukan pendidikan kesehatan untuk meningkatkan pengetahuan dan sikap siswa. Pendidikan kesehatan non formal dapat dilakukan dengan menggunakan berbagai metode antara lain ceramah dan diskusi.

Menanggapi hal tersebut, maka tertarik untuk diteliti "pengaruh pendidikan kesehatan melalui metode ceramah dengan metode diskusi terhadap pengetahuan dan sikap tentang NAPZA pada siswa SMU Swasta RK Deli Murni di Diski Kecamatan Sunggal kabupaten Deli serdang".

Penelitian ini bertujuan untuk mengetahui pengaruh pendidikan kesehatan melalui metode ceramah dengan metode diskusi terhadap pengetahuan dan sikap tentang NAPZA kepada siswa SMU Swasta RK Deli Murni Diski Kecamatan Sunggal Kabupaten Deli Serdang. METODE PENELITIAN

Jenis penelitian menggunakan pendekatan kuantitatif, metode yang 
digunakan dalam penelitian ini adalah Quasi-Experimental Design (eksperimen semu), dengan rancangan Pretest-Posttes Group Design (Campbell, 1966). Penelitian dilaksanakan di SMU Swasta RK Deli Murni Diski Kecamatan Sunggal Kabupaten Deli Serdang.

Populasi adalah seluruh siswa di SMU Swasta RK Deli Murni Diski Kecamatan Sunggal Kabupaten Deli Serdang berjumlah 176 orang. Besar sampel minimum pada penelitian ini adalah 30 orang yang dibagi menjadi 2 kelompok yaitu kelompok yang diberikan pendidikan kesehatan dengan metode ceramah sebanyak 30 orang dan metode diskusi sebanyak 30 orang dengan kelas yang berbeda. Analisis yang dilakukan pada penelitian ini terbagi dua (2) analisis yaitu analisis univariat, dan bivariat dengan uji T-Independent.

\section{HASIL DAN PEMBAHASAN \\ Karakteristik Siswa berdasarkan Metode Ceramah dan Metode Diskusi}

Siswa kelompok ceramah lebih banyak yang berumur 16 tahun sebanyak 20 orang $(66,7 \%)$ dengan jenis kelamin perempuan sebanyak 16 orang $(53,3 \%)$ dan siswa lebih banyak mendapat sumber informasi tentang NAPZA dari televisi sebanyak 16 orang $(53,3 \%)$, sedangkan siswa pada kelompok diskusi lebih banyak yang berumur 16 tahun sebanyak 15 orang $(50,0 \%)$ dengan jenis kelamin lakilaki sebanyak 20 orang $(66,7 \%)$ dan sumber informasi yaitu televisi sebanyak 17 orang $(56,7 \%)$. Siswa mayoritas berpengetahuan kurang baik (100\%) sebelum dilakukan pendidikan kesehatan pada metode ceramah dan diskusi, sedangkan sikap siswa pada metode ceramah sebanyak 18 orang $(48,6 \%)$ dan metode diskusi sebanyak 19 orang $(51,4 \%)$.

Berdasarkan hasil uji chi-square pada variabel umur, pendidikan dan sumber informasi menunjukkan bahwa tidak ada hubungan umur $(\mathrm{p}=0,401)$, pendidikan $(\mathrm{p}=0,118)$, sumber informasi $(\mathrm{p}=0,286)$, pengetahuan dan sikap $(\mathrm{p}=0,791)$ dengan pendidikan kesehatan metode ceramah dan metode diskusi. Hasil penelitian ini menunjukkan bahwa baik metode ceramah maupun metode diskusi homogen dalam hal umur, pendidikan, sumber informasi, pengetahuan dan sikap sebelum dilakukan pendidikan kesehatan.

Tabel 1 Distribusi Karakteristik Siswa

\begin{tabular}{lccccc}
\hline \multirow{2}{*}{ Karakteristik } & \multicolumn{2}{c}{$\begin{array}{c}\text { Kelompok I } \\
\text { Ceramah }\end{array}$} & \multicolumn{2}{c}{$\begin{array}{c}\text { Kelompok II } \\
\text { Diskusi }\end{array}$} & \multirow{2}{*}{$\boldsymbol{p}$} \\
\cline { 2 - 4 } & n & \% & n & \% & \\
\hline Umur (tahun) & 6 & 20,0 & 10 & 33,3 & \\
15 & 20 & 66,7 & 15 & 50,0 & 0,401 \\
16 & 4 & 13,3 & 5 & 16,7 & \\
17 & & & & & \\
Jenis Kelamin & 14 & 46,7 & 20 & 66,7 & \multirow{2}{*}{0,118} \\
$\quad$ Laki-laki & 16 & 53,3 & 10 & 33,3 & \\
$\quad$ Perempuan & & & &
\end{tabular}

\section{Sumber Informasi}




$\begin{array}{lccccc}\text { Televisi } & 16 & 53,3 & 17 & 56,7 & \\ \text { Radio } & 6 & 20,0 & 2 & 6,6 & 0,286 \\ \text { Koran/Majalah } & 8 & 26,7 & 11 & 36,7 & \end{array}$

\section{Pengetahuan}

Sebelum

$\begin{array}{lcccc}\text { Kurang } & 30 & 100 & 30 & 100 \\ \text { Baik } & 0 & 0 & 0 & 0\end{array}$

Sikap Sebelum

\begin{tabular}{llllll} 
Kurang & 18 & 48,6 & 19 & 51,4 & 0,791 \\
Baik & 12 & 52,2 & 11 & 47,8 & \\
\hline
\end{tabular}

Pengetahuan dan Sikap Siswa Sebelum dan Sesudah Metode Ceramah tentang NAPZA

Sebelum metode ceramah diperoleh nilai rata-rata pengetahuan 7,40 meningkat menjadi 12,43 . Nilai terkecil yang diperoleh siswa sebelum dilakukan metode ceramah tentang NAPZA hanya mencapai 3 poin dan terbesar hanya 9 poin dan sesudah dilakukan metode ceramah tentang NAPZA nilai terkecil yang diperoleh oleh remaja adalah 10 poin dan terbesar mencapai 14 poin.

Tabel 2 Skor Pengetahuan dan Sikap Siswa Sebelum dan Sesudah Metode Ceramah tentang NAPZA di SMU RK Deli Murni Tahun 2016

\begin{tabular}{lccccc}
\hline \multicolumn{1}{c}{ Variabel } & $\mathbf{n}$ & $\overline{\boldsymbol{x}}$ & SD & Min & Maks \\
\hline Pengetahuan & & & & & \\
Sebelum Ceramah & 30 & 7,40 & 1,47 & 3 & 9 \\
Sesudah Ceramah & 30 & 12,43 & 1,25 & 10 & 14 \\
\hline Sikap & & & & & \\
Sebelum Ceramah & 30 & 37,86 & 2,67 & 33 & 44 \\
Sesudah Ceramah & 30 & 44,93 & 1,55 & 42 & 48 \\
\hline
\end{tabular}

Pengetahuan dan Sikap Siswa Sebelum dan Sesudah Metode Diskusi tentang tentang NAPZA

Pengetahuan sebelum metode diskusi diperoleh nilai rata-rata pengetahuan 7,20 meningkat menjadi 13,13. Nilai terkecil yang diperoleh siswa sebelum dilakukan metode diskusi tentang NAPZA hanya mencapai 3 poin dan terbesar hanya 11 poin dan sesudah dilakukan
Sebelum metode ceramah tentang NAPZA diperoleh nilai ratarata sikap 37,86 meningkat menjadi 44,93. Nilai terkecil yang diperoleh remaja sebelum dilakukan metode ceramah tentang NAPZA hanya mencapai 33 poin dan terbesar hanya 44 poin dan sesudah dilakukan metode ceramah tentang NAPZA nilai terkecil yang diperoleh oleh remaja adalah 42 poin dan terbesar mencapai 48 poin. 
hanya 44 poin dan sesudah dilakukan metode diskusi tentang NAPZA nilai terkecil yang diperoleh oleh remaja

Tabel 3 Skor Pengetahuan dan Sikap Siswa Sebelum dan Sesudah Metode Diskusi tentang tentang NAPZA di SMU RK Deli Murni Tahun 2016

\begin{tabular}{lccccc}
\hline \multicolumn{1}{c}{ Variabel } & $\mathbf{n}$ & $\overline{\boldsymbol{x}}$ & SD & Min & Maks \\
\hline Penegetahuan & & & & & \\
Sebelum Diskusi & 30 & 7,20 & 1,06 & 5 & 11 \\
Sesudah Diskusi & 30 & 13,13 & 0.86 & 11 & 14 \\
\hline Sikap & & & & & \\
Sebelum Diskusi & 30 & 37,13 & 2,20 & 33 & 44 \\
Sesudah Diskusi & 30 & 46,06 & 1,38 & 43 & 48 \\
\hline
\end{tabular}

Pengaruh Pendidikan Kesehatan melalui Metode Ceramah dan Metode Diskusi dalam meningkatkan Pengetahuan dan Sikap Siswa tentang NAPZA

Selanjutnya, dilakukan uji $t$ independent untuk melihat pengaruh pendidikan kesehatan melalui metode ceramah dan metode diskusi.

Terdapat perubahan pengetahuan

tentang NAPZA antara metode ceramah dengan metode diskusi $(\mathrm{p}=0,031)$. Perubahan pengetahuan lebih besar pada metode diskusi. Terdapat perubahan sikap tentang NAPZA antara metode ceramah dengan metode diskusi $(p=0,011)$. Perubahan sikap lebih besar pada metode diskusi.

Tabel 4 Pengaruh Pendidikan Kesehatan melalui Metode Ceramah dan Metode Diskusi dalam meningkatkan Pengetahuan dan Sikap Siswa tentang NAPZA di SMU Swasta RK Deli Murni Diski Tahun 2016

\begin{tabular}{lccc}
\hline \multicolumn{1}{c}{ Variabel } & $\overline{\boldsymbol{x}}$ & $\mathbf{t}$ & $\boldsymbol{p}$ \\
\hline $\begin{array}{l}\text { Perubahan Pengetahuan } \\
\text { Ceramah }\end{array}$ & 5,03 & $-2,20$ & 0,031 \\
$\quad$ Diskusi & 5,93 & & \\
\hline $\begin{array}{l}\text { Perubahan Sikap } \\
\text { Ceramah }\end{array}$ & 7,07 & $-2,62$ & 0,011 \\
$\quad$ Diskusi & 8,93 & & \\
\hline
\end{tabular}

Pengaruh Pendidikan Kesehatan melalui Metode Ceramah dan Metode Diskusi terhadap Pengetahuan Siswa tentang NAPZA

Adanya perubahan pengetahuan siswa sebelum dan sesudah dilakukan metode diskusi yaitu terjadinya peningkatan rata-rata pengetahuan sebelum 7,20 menjadi
13,13 sesudah diberikan metode ceramah.

Hasil penelitian diperoleh bahwa pendidikan kesehatan melalui metode diskusi lebih efektif terhadap pengetahuan dibandingkan metode ceramah. Proses belajar pada hakekatnya adalah proses komunikasi, yaitu penyampaian informasi/pesan dari sumber pesan melalui saluran/media tertentu ke 
penerima pesan. Sumber pesan bisa guru, siswa, dan orang lainnya, sedangkan salurannya adalah media pendidikan baik media cetak maupun elektronik.

Pada penelitian ini penceramah adalah peneliti sendiri. Pada penelitian ini ceramah dilakukan dengan tehnik ceramah dimodifikasi dengan tanya jawab sesudah penyampaian materi. Terjadi interaksi langsung antara narasumber dan responden yang menyebabkan adanya diskusi sehingga penyuluhan lebih menarik dan tidak membosankan.

Penyuluhan ini menggunakan materi yang singkat, $L C D$ dan sound system untuk mempermudah penyampaian materi ceramah. Mengenai kelekatan pada ingatan dari bahan yang disampaikan, Socony di Amerika dalam Lunandi (1993) mengadakan penelitian yang hasilnya yaitu dengan menyampaikan sekaligus menceritakan dan mempertunjukkan lebih lekat dalam ingatan selama 3 jam kemudian $(85 \%)$ dibandingkan dengan menyampaikan hanya menceritakan $(70 \%)$ atau hanya mempertunjukkan (27\%). Berarti dalam suatu ceramah diharapkan pemberi informasi tidak hanya berbicara saja tetapi juga dapat menunjukkan sesuatu yang dapat dilihat oleh penerima informasi.

Dari penjelasan yang telah diuraikan dapat disimpulkan bahwa terjadi peningkatan pengetahuan siswa sebelum dan sesudah pendidikan kesehatan dengan metode ceramah.

Pelaksanaan pendidikan memberikan hasil yang lebih baik apabila sesuai dengan karakteristik sasaran. Implementasi proses pendidikan dengan sasaran anak- anak berbeda dengan implementasi proses pendidikan dengan sasaran remaja atau orang tua.

Remaja yang mendapat penyuluhan NAPZA dengan metode ceramah, lebih sedikit menggunakan modalitas belajar. Mereka mendapatkan informasi melalui modalitas belajar auditorial dan lebih menekankan aspek kognitif saja. Metode ceramah kurang memungkinkan peserta didik mengolah informasi secara mendalam. Metode ceramah merupakan teknik yang melibatkan peran aktif komunikator (pemberi pesan) saja, sehingga bagi pendengar kebutuhan untuk berargumentasi dan menghayati informasi yang diterima relatif sedikit. Metode ceramah juga kurang memungkinkan individu membangun pengetahuan dan kemampuan melalui pengalaman nyata yang dialami.

Sesuai dengan penelitian Sukini (2009) bahwa ada pengaruh pendidikan kesehatan yang diberikan kepada kelompok eksperimen dalam peningkatan pengetahuan siswa kelas III SMK Muhammadiyah Kartasura. Implikasi program pencegahan penyalahgunaan NAPZA di sekolah, seharusnya terintegrasikan dalam kurikulum sekolah, menjadi bagian dari kurikulum tentang kesehatan, dilaksanakan secara reguler dan kontinyu (Munro, 1998).

\section{Pengaruh Pendidikan Kesehatan melalui Metode Ceramah dan Metode Diskusi terhadap Sikap Siswa tentang NAPZA}

Adanya perubahan sikap siswa sebelum dan sesudah dilakukan metode diskusi yaitu terjadinya peningkatan rata-rata sikap sebelum 37,13 menjadi 46,06 sesudah diberikan metode diskusi. 
Penyuluhan dengan metode ceramah sebagai proses perubahan sikap yang menuntut persiapan dan pengetahuan yang memadai bagi penyuluh maupun sasarannya. Petugas kesehatan sebagai penyuluh berperan dalam menyuluh siswa tentang NAPZA untuk mengubah sikap setelah penyuluhan.

Program

penyalahgunaan

diimplemantasikan

memberikan

pengetahuan, sikap dan ketrampilan

sosial yang lebih baik pada program yang bersifat interaktif, banyak melibatkan partisipasi dalam aktivitas-aktivitas kegiatan sehingga dapat lebih mengembangkan ketrampilan sosial.

Sesuai dengan penelitian Puspandari (2008) bahwa pada kelompok perlakuan dengan ceramah interaktif dan audiovisual ini sesuai dengan penelitian yang mengatakan bahwa pendidikan kesehatan seksual yang diberikan kepada remaja dalam upaya pencegahan HIV/AIDS tidak berpengaruh terhadap peningkatan sikap mereka. Hasil penelitian lain mengatakan bahwa pendidikan kesehatan reproduksi dengan ceramah interaktif dan audiovisual meningkatkan sikap remaja terhadap kesehatan reproduksi namun peningkatan tersebut secara statistik tidak bermakna. Berdasarkan uraian tersebut maka pengembangan sikap positif terhadap pencegahan penyalahgunaan Napza, perlu dilakukan intervensi tidak hanya melalui pendidikan kesehatan namun juga melalui berbagai kegiatan lain dan forum yang ada secara berkesinambungan.

Sesuai dengan penelitian Sukini (2009) bahwa ada pengaruh pendidikan kesehatan yang diberikan kepada kelompok eksperimen terhadap sikap siswa kelas III SMK Muhammadiyah Kartasura. Hasil pengujian pengetahuan dan sikap siswa pada kedua kelompok tersebut menunjukkan bahwa pemberian pendidikan kesehatan berdampak pada peningkatan pengetahuan dan sikap tentang NAPZA pada siswa kelas III SMK Muhammadiyah Kartasura tahun 2008.

\section{KESIMPULAN}

1. Pendidikan kesehatan melalui metode ceramah dan metode diskusi berpengaruh terhadap pengetahuan siswa tentang NAPZA..

2. Pendidikan kesehatan melalui metode ceramah dan metode diskusi berpengaruh terhadap sikap siswa tentang NAPZA..

3. Pendidikan kesehatan melalui metode diskusi lebih efektif terhadap pengetahuan dan sikap dibandingkan metode ceramah.

\section{SARAN}

1. Kepada SMU Swasta RK Deli Murni Diski agar memberikan pendidikan kesehatan khususnya NAPZA dengan metode diskusi karena terbukti lebih unggul dalam meningkatkan pengetahuan dan sikap dari pada metode ceramah.

2. Pihak kerja sama dengan Dinas Kesehatan dalam memberikan pendidikan kesehatan khususnya tentang NAPZA untuk meminimalisir terjadinya penyalahgunaan NAPZA.

\section{DAFTAR PUSTAKA}


BNN, 2014. Analisa Data Pencegahan dan Pemberantasan Penyalahgunaan dan Peredaran Gelap Narkoba Badan Narkotika Nasional. Jakarta.

Campbell,T.D. 1966. Experimental and Quasi-Experimental Design For Research. U.S.A: Houghton Mifflin Company.

Kusmiran, E., 2001. Kesehatan Reproduksi Remaja dan Wanita. Salemba Medika. Jakarta

Lunandi, A.G., 1993. Pendidikan Orang Dewasa, Sebuah Uraian Praktis Untuk Pembimbing Penatar Pelatih dan Penyuluh Lapangan, Gramedia. Jakarta.

Mardiani, 2013, Pengaruh Pendidikan Kesehatan Tentang Narkoba Terhadap Pengetahuan dan sikap Remaja di SMA Negeri 5 Pematang Siantar Tahun 2013. Tesis Pascasarjana Ilmu Kesehatan Masyarakat Universitas Sumatera Utara. Medan.

Munro, G., 1998. School-based Drug Education: Realistic Aims or Certain Failure. Centre for Drug Studies. Australian Drug Foundation. Dalam http:// www.adf.org.au/ cyds/papers/sdet.
Puspandari, R.; Sunarsih, IM.; Widyatama, R., 2008. Kontribusi Testimoni dalam Meningkatkan Efektivitas Pendidikan Kesehatan tentang NAPZA di Kabupaten Sleman. Berita Kesehatan Masyarakat. 24(3):130-138

Sukini. 2009. Pengaruh Pendidikan Kesehatan tentang NAPZA terhadap Pengetahuan dan Sikap Siswa Kelas III SMK Muhammadiyah Kartasura. Skripsi Faklutas Ilmu Kesehatan Universitas Muhammadiyah Surakarta.

Sumiati, 2009. Asuhan Keperawatan Pada Klien penyalahgunaan dan Ketergantungan Napza, Trans Info Media, Jakarta.

Undang-Undang No. 5 Tahun 1997 Psikotropika

Undang-Undang Nomor 22 Tahun 1997 tentang Narkotika

Undang-Undang No. 23 Tahun 2003 tentang Perlindungan terhadap Anak

Undang-Undang No. 36 Tahun 2009 tentang Kesehatan

Wawan dan Dewi, 2011. Teori Pengukuran Pengetahuan, Sikap dan Perilaku Manusia. Nuha Medika. Yogyakarta. 